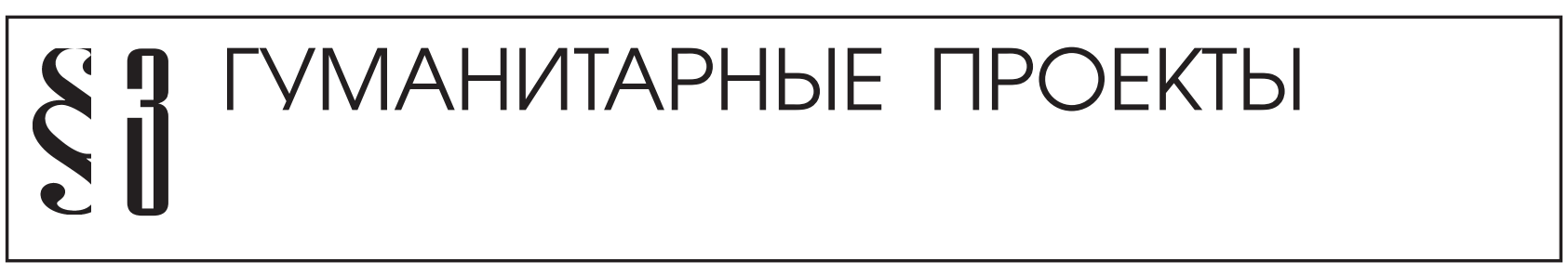

Урсул А.Д., Урсул Т.А.

\title{
НАПРАВЛЕНИЯ И ОСОБЕННОСТИ СТАНОВЛЕНИЯ ОБРАЗОВАНИЯ ДЛЯ УСТОЙЧИВОГО РАЗВИТИЯ В РОССИИ: К ЗАВЕРШЕНИЮ ДЕКАДЫ ООН
}

Аннотация: Обсуждается проблема развертьввания образования в интересах устойчивого развития в России как перед Декадой ОУР, так и во время её проведения. Рассмотрены официальные документьл общемирового и российского уровня, необходимье для внедрения конщепции УР в образовательную деятельность в стране. Сделан акцент на особенностях восприятия идеи УР и становления образования для УР в России, подготовки учебных и учебно-методических материалов экологического образования в контексте УР в высшей школе, начиная с Конферениии ООН по окружсающей среде и развитию. Рассматривается проблема расширения концепции УР, что важнно учитьвать в становлении ОУР, которое в силу этих обстоятельств долюен будет расширять свою сферу в научно-образовательном пространстве. Используется исторический и эволючиионный подходы к становлению образования для устойчивого развития в России, а также системно-сравнительный подход для выявления общих тенденций в глобальном мире развертывания экологического образования для устойчивого развития Впервые выявлены общие и специфические черты и тендениии развития образования для устойчивого развития как нового феномена в мировом сообществе и особенно в России. Показано, что наряду с принятой в мире экологической трактовкой, в России развивалась такюе концепции опережсающего образования, глобального образования и образования для устойчивого развития на основе новьх идей об обеспечении безопасности через устойчивое развитие. Подчеркнуто, что в дальнейшем образование для устойчивого развития должно использовать более иирокую и системно-иелостную концепџию глобальной устойчивости, не сводимой только к триаде - экономика, сочиальная сфера, экология.

Review: The authors discuss the problem of education for sustainable development (ESD) of Russia before the UN Decade and within its period. The authors evaluate official documents of global and Russian level which are necessary for the introduction of the concept of sustainable development in the education in Russia. Special attention is paid to the perception of the idea of sustainable development and formation of education for the purposes of sustainable development in Russia, preparation of teaching and teaching-methodological manuals for environmental education within the framework of sustainable development within the system of higher education, starting with the Conference of the UN on environment and development. The authors evaluate the problem of widening the scope of sustainable development, which has to be taken into consideration within the framework of formation of the ESD, since it shall have to widen its range in the field of scientific education. The authors employ historical and evolution approaches towards the formation of education for the sustainable development in Russia, as well as a systemic comparative approach in order to reveal the general tendencies in the global world of development of environmental education for the sustainable development. For the first time the authors reveal general and specific features and tendencies in education development for sustainable development as a new phenomenon in the global community, and especially in Russia. I is shown that in addition to the globally accepted environmental interpretation, the Russia gained a concept of preemptive education, global education and education for sustainable development based upon the new ideas on guaranteeing security via sustainable development. It is stressed that in the future education for sustainable development should involve wider and more systemically comprehensive concept of global sustainability, which is not limited to the triad of economics, social sphere and environment.

Ключевые слова: Безопасность, ВСУР, нащиональная безопасность, опережаюшее образование, Рио +20, устойчивое образование, устойчивое развитие, экологическое образование, ЭОУР, ЮНСЕД.

Keywords: Security, International Summit on Sustainable Development, national security, preemptive education, Rio+20, sustainable education, sustainable development, environmental education, environmental education for sustainable development, UN Conference on Environment and Development. 


\section{Введение}

$\mathrm{B}$ о всем мире идет интенсивный поиск новых стратегий и моделей образования XXI века, которые могли бы удовлетворять потребности нынешних и будущих поколений человечества, поставившего цель своего выживания и сохранения окружающей природной среды. Основная идея предлагаемого эволюционного подхода к исследованию перспектив мирового образования заключается в том, что в образовании будут происходить трансформации, которые тесно сопряжены с эволюционными изменениями всего цивилизационного процесса и взаимодействия общества и природы. Предполагается, что это будет не какая-то одна «конечная» модель образования XXI века, а эволюционный ряд моделей и стратегий образовательных процессов и систем, способствующих становлению новой цивилизации, обеспечивающей выживание человечества и сохранение биосферы.

Одну из новых и наиболее важных моделей образования необходимо связать со стратегией устойчивого развития, к которой человечество уже начинает переходить в XXI в., согласно решениям ООН. Основные контуры новой модели цивилизационного развития III тысячелетия и его важнейшей подсистемы - образования - должны сформироваться уже в ближайшие десятилетия.

\section{Межудународные документы по образованию для устойчивого развития}

Для становления образования для устойчивого развития (ОУР) в России должна существовать соответствующая документальная база, которой будут руководствоваться учебные заведения в своей деятельности. Среди таких официальных документов необходимо выделить прежде всего международные документы, особенно документы $\mathrm{OOH}$, начиная с ЮНСЕД в Рио-де-Жанейро в 1992 г. В декабре 2002 г. Генеральная Ассамблея Организации Объединенных Наций приняла резолюцию 57/254, в соответствии с которой было провозглашено Десятилетие образования в интересах устойчивого развития (ДОУР), охватывающее 2005-2014 гг.

Причем ЮНЕСКО было поручено стать ведущим учреждением в вопросах проведения Десятилетия. Цели ДОУР, как декларирует ЮНЕСКО - это провозглашение образования в качестве фундамен- та создания более устойчивого общества людей и интеграция устойчивого развития в системе образования на всех его уровнях. Цели ДОУР - укрепление международного сотрудничества в области развития и обмен инновационными методами обучения по программам, практике и политике устойчивого развития. Ясно, что ОУР - это ключевой инструмент достижения Целей развития тысячелетия, а также тех целей УР, которые будут выработаны в ближайшее время во исполнение решений Рио+20.

ЮНЕСКО особое внимание уделяет проблемам образования в интересах устойчивого развития. Так, ещё в 1998 г. на Всемирной конференции по высшему образованию в Женеве была принята «Всемирная декларация о высшем образовании для 21 века: подходы и практические меры», в которой отмечается, что образование является важнейшей опорой устойчивого развития, способной удовлетворять современные и будущие потребности общества ${ }^{1}$.

В целях устойчивого развития (УР) ЮНЕСКО призвана переориентировать свои программы, внеся в них необходимые изменения, с тем, чтобы содействовать переходу к устойчивому развитию. Улучшение качества образования и переориентация его целей и задач на УР должны стать одним из приоритетов ЮНЕСКО. В Международном плане мероприятий для реализации ДОУР, принятом ЮНЕСКО, устанавливаются широкие рамки для всех партнеров, которые пожелали внести свой вклад в проведение ДОУР².

В последующих форумах под эгидой $\mathrm{OOH}$, в частности ВСУР в Йоханнесбурге в 2002 г. и особенно - крупных международных конференциях по образованию для устойчивого будущего, состоявшихся вначале Индии, а затем в Германии, были отмечены начало и дальнейшее развертывание провозглашенной $\mathrm{OOH}$ Декады по образованию для устойчивого развития. Образование является фундаментом УР и об этом шла речь в Повестке дня на 21 век принятой на саммите в Рио-де-Жанейро

\footnotetext{
${ }^{1}$ См.: Всемирная декларация о высшем образовании для XXI века: подходы и практические меры. [Электронный ресурc]. URL: http://www.conventions.ru/view_base. php?id=1496 (дата обращения: 04.07.2014)

${ }^{2}$ См.: Проект Международного плана мероприятий в рамках Десятилетия образования в интересах устойчивого развития Организации Объединенных Наций [Электронный ресурс]. URL: http unesdoc unesco org images $0013001390139023 \mathrm{r}$ pdf (дата обращения: 04.07.2014)
} 
в 1992 г. Это важное положение было подтверждено на саммите в Йоханнесбурге и опять - на саммите Рио +20 в $2012 \Gamma^{3}$.

Важное значение имеет принятые в процессе подготовки Рио+20 «Обязательства учреждений высшего образования в отношении практики обеспечения устойчивости в связи с Конференцией Организации Объединенных Наций по устойчивому развитию», согласно которым руководители вузов и их подразделений обязуются поддерживать международные усилия по переходу к устойчивому развитию (кстати, в них приняли участие восемь вузов России, включая МГИМО и МГУ им. М.В. Ломоносова в «лице» факультета глобальных процессов, причем этот последний стараниями организаторов сайта ООН по ошибке попал в Румынию) ${ }^{4}$. То есть, фактически, создаваемая сеть институтов высшего образования начинает играть роль особого транснационального актора, принимающего на себя ряд обязательств на международно-политическом уровне. Подписание руководителями образовательных учреждений многих стран мира упомянутого Обязательства о содействии методам обучения, которые помогут студентам приобрести знания, умения и навыки, необходимые для создания более устойчивого общества, будут содействовать исследованиям в высших учебных заведениях вопросов устойчивого развития и они заслуживают распространения в других вузах как нашей страны, так и всего мира.

Среди других важных документов международного уровня - «Заявление об образовании в интересах устойчивого развития» на Конференции министров Европы в Киеве, но главное - речь идет о Стратегии ЕЭК ООН для образования в интересах устойчивого развития, принятой к реализации в марте 2005 г., , а также об «Основных положениях

${ }^{3}$ См.: Итоговый документ Конференции ООН по устойчивому развитию «Будущее, которого мы хотим» [Электронный pecypc]. URL: http://www.un.org/ru/sustainablefuture (дата обращения: 04.07.2014)

${ }^{4}$ Higher Education Sustainability Initative for Rio+20. [Электронный ресурc]. URL: http://www.uncsd2012.org/index.php ?page=view\&nr=341\&type=12\&menu=35 (дата обращения: 04.07.2014)

${ }^{5}$ Стратегия ЕЭК ООН для образования в интересах устойчивого развития [Электронный ресурc]. URL: http://www.ustoichivo.ru/biblio/view/145.html (дата обращения: 04.07.2014) проекта плана осуществления Десятилетия образования в целях устойчивого развития» ${ }^{6}$.

На Всемирном саммите по устойчивому развитию в 2002 г. было уделено внимание проблемам образования. В разделе «Средства осуществления» Плана выполнения решений ВСУР (ст. 116) отмечается, что «для продвижения по пути устойчивого развития абсолютно необходимо образование». При этом ставится ряд целей с деталями их реализации:

1. добиться достижения целей тысячелетия в области развития, касающихся обеспечения всеобщего начального образования, гарантировав при этом, чтобы к 2015 году все дети, как мальчики, так и девочки, могли повсеместно пройти полный курс начальной школы;

2. устранить гендерный разрыв в области начального и среднего образования к 2005 году, как это предусматривается в Дакарских рамках действий: образование для всех, и на всех уровнях образования на позднее 2015 года, для достижения сформулированных в Декларации тысячелетия целей в области развития, за счет принятия мер к обеспечению, среди прочего, равного доступа ко всем уровням и формам образования, подготовки и расширения потенциала благодаря учету гендерной проблематики и созданию систем образования, учитывая гендерный фактор.

В других статьях упомянутого Плана речь идет об интеграции вопросов устойчивого развития в системе образования на всех уровнях, с тем чтобы оказывать содействие образованию как ключевому фактору перемен (ст. 121), о поддержании образования для поощрения устойчивого развития и что особенно важно - рекомендация Генеральной

6 Заявление об образовании в интересах устойчивого развития // Конференция министров «Окружающая среда для Европы». Киев. 2003; Основные положения проекта плана осуществления «Десятилетия образования в целях устойчивого развития». ЮНЕСКО. 2003; Элиас В.В. Обзор важнейших международных соглашений в области образования для устойчивого развития // Образование для устойчивого развития: Материалы Всероссийского совещания «Образование для устойчивого развития»/ Под ред. Н.С.Касимова, В.С.Тикунова. Смоленск. 2003; она же. Навстречу Десятилетию ООН по образованию в интересах устойчивого развития [Электронный ресурc]. URL: http://www.ecoaccord.org/ edu/esd_general.htm; http://www.myshared.ru/slide/350503/ (дата обращения: 04.07.2014) 


\section{Политика и общество 7 (115) • 2014}

Ассамблее ООН рассмотреть вопрос о провозглашении десятилетия, начинающегося с 2005 года, десятилетием образования в интересах устойчивого развития (ст. 124).

Эксперты Экономической комиссии ООН (UNECE) разработали проект Стратегии образования для УР для региона государств Европы, Центральной Азии и Северной Америки, которые объединяют 55 стран с различными уровнями экономического развития ${ }^{7}$. В 2005 г. в Вильнюсе совещанием высокого уровня представителей министерств охраны окружающей среды и образования была принята «Стратегия Европейской экономической комиссии ООН для образования в интересах устойчивого развития». Стратегия явилась первым официальным документом регионального масштаба (включающим более 25\% стран мирового сообщества) в области создания новой модели образования, способной обеспечить выживание цивилизации. Если учесть, что в Индии в январе 2005 г. состоялся под эгидой ООН общемировой форум по ОУР, то можно считать, что мировое сообщество отреагировало на объявление декады 2005-2014 гг. переходным десятилетием для начала формирования нашего общего устойчивого будущего. Причем становится очевидным, что ОУР оказывается не только предпосылкой достижения устойчивого развития, но и приоритетным его средством, т.е. можно сказать, что переход к УР начинается со становления образования в интересах устойчивого развития.

Нужно сказать, что в Стратегии так или иначе нашли отражение работы российских ученых в области ОУР, которые были выполнены еще за десять лет до принятия этой Стратегии ${ }^{8}$. В самом тексте Стратегии говорится о том, что

\footnotetext{
${ }^{7}$ См.: Проект Стратегии ЕЭК ООН для образования в интересах устойчивого развития // Образование для устойчивого развития. Материалы семинара «Экологическое образование и образование для устойчивого развития» / Под ред. Н.С. Касимова. М. - Смоленск, 2004. Проект был принят в октябре 2004 г. в Женеве на 11 сессии ЕЭК ООН и Комитета по экологической политике ЭКОСОС ООН.

${ }^{8}$ См.: Экологическое образование и устойчивое развитие / Под ред. А.Д. Урсула. М.: РАГС, 1996; Урсул А.Д. Переход России к устойчивому развитию. Ноосферная стратегия. М.: Ноосфера, 1998; Ващчекин Н.П. Делокаров К.Х., Урсул А.Д. Образование и устойчивое развитие. Концептуальные проблемы. М., 2001; Урсул А.Д., Демидов Ф.Д. Образование для устойчивого развития: научные основы. М.: РАГС, 2004.
}

в этом документе, воплощен опыт, накопленный как в самом упомянутом регионе, так и во всем мире. Эта Стратегия является также вкладом в подготовленный ЮНЕСКО план осуществления плана Десятилетия образования ООН в интереcax УР и плана выполнения решений ВСУР в Йоханнесбурге. Учтен также опыт образовательных учреждений стран ЕЭК ООН, в которых уже началось развертывание ОУР, а также ряда международных организаций и НПО.

В Стратегии отмечается, что она должна опираться на достижения образования в различных странах, на научный потенциал и активное участие гражданского общества, но вместе с тем необходимо решать новые задачи с целью эффективного осуществления принципов ОУР, учитывая его междисциплинарный и межведомственный характер и создание адекватной материально-технической и институциональной поддержки.

Целью Стратегии является поощрение государств, к правительствам которых она адресована (членов ЕЭК ООН), к включению в свои системы формального образования в рамках всех соответствующих учебных дисциплин, а также в неформальное образование и просвещение. Это будет содействовать освоению знаний и специальных навыков в области УР, повысит их компетентность, расширит их возможности вести здоровый и плодотворный образ жизни в гармонии с природой, проявлять заботу о социальных ценностях, равноправии полов и культурном многообразии.

В соответствии с этой целью сформулированы следующие задачи:

1) обеспечение того, чтобы механизм политики, нормативно-правовая база и организационные основы служили опорой для ОУР;

2) содействие УР через посредство формального и неформального обучения и просвещения;

3) освоение педагогами знаний, позволяющих включить вопросы УР в преподаваемые ими предметы;

4) обеспечение доступности учебных средств и учебно-методических пособий для ОУР;

5) содействие научным исследованиям в области ОУР и развитию ОУР;

6) укрепление сотрудничества в области ОУР на всех уровнях в пределах региона ЕЭК ООН ${ }^{9}$.

\footnotetext{
${ }^{9}$ См.: Образование для устойчивого развития. С. 9-10.
} 
В Стратегии подчеркивается, что ОУР требует переориентации основного внимания с обеспечения знаний на проработку проблем и отыскание возможных решений. Причем все это может и должно повлиять на методы преподавания и структуру учебных программ, как традиционных предметов и дисциплин, так и междисциплинарный синтез научно-образовательного знания, открывая возможности для более многостороннего и системного подхода. Это потребует «от педагогов отказаться от роли исключительно передаточного звена, а от учащихся - от роли исключительно получателей, вместо этого им следует действовать совместно» ${ }^{10}$.

Особое внимание предполагается уделять первоначальной подготовке и переподготовке педагогов и создание для них возможностей для обмена опытом среди преподавателей, включившихся в инновационный процесс становления ОУР. Усиление инновационного акцента получается при тесной увязке с соответствующими результатами в области теории и практики УР. Овладение основами ОУР зависит от содержания, качества и наличия учебно-методических материалов по проблемам УР, которых, конечно, пока очень мало, их даже нет в ряде стран, где подавляющая часть населения и не слышала об УР.

В Стратегии отмечается, что для того, чтобы ОУР стало эффективным, необходимо проблемы УР интегрировать во все учебные дисциплины, программы и курсы, а также организовать конкретные курсы и программы, посвященные проблемам УР, и для этого применять широкий диапазон методов обучения, в основном развивающих созидательнотворческое начало в сознании учащихся.

Учитывая, что и Болонский процесс, создающий общеевропейское пространство высшего образования и общеевропейское пространство исследований, также фактически уже стартовали с 2005 г., важно их соединить в единую образовательную и даже научно-образовательную систему, причем этот процесс, по крайней мере в Европе наиболее успешно идет для магистерского уровня образования.

Наука и образование при переходе к устойчивому развитию должны соединиться в единый общепланетарный научно-образовательный процесс, работающий на созидание общества с УР мыслимого в перспективе в качестве глобальной сферы разума.

${ }^{10}$ См. там же. С. 14.
Начало этого процесса мы видим не только в развитии Болонского процесса, но главное - в решениях всемирных форумов ООН, посвященных проблемам УР. Так, на ВСУР было уделено внимание проблемам образования, причем объявлено, что начиная с 2005г. не только развернется всемирный переход к устойчивому будущему, но и будет осуществляться рекомендация Генеральной Ассамблее $\mathrm{OOH} \mathrm{об} \mathrm{объявлении} \mathrm{Десятилетия} \mathrm{образования} \mathrm{в} \mathrm{ин-}$ тересах УР (статья 124) ${ }^{11}$. И это не случайное совпадение начала двух процессов, один из которых должен опережать все остальные: ведь с помощью образования новой - устойчивой ориентации - необходимо сформировать сознание людей, готовых и способных обеспечить выживание цивилизации и реализовать переход к устойчивому будущему.

\section{Российская документальная база ОУР}

Что касается российских официальных документов, то цель перехода к УР была впервые обозначена в «Национальной доктрине образования РФ», принятой Правительством РФ в 2000 г. Однако нужно иметь в виду, что в какой-то мере модель образования, очерченная в упомянутой доктрине является одним из вариантов «переходной» модели образования. Трансляционная модель образования, адекватная традиционному обществу, не просто дополняется, но фактически обязана смениться новой моделью, которую уместно назвать переходной, или антикризисной. Переходной - потому, что должна идти смена моделей развития, антикризисной - потому, что образование должно включаться в общий процесс выхода из кризиса как глобальных, так и регионально-локальных антикризисных действий. И было бы странно считать, что антикризисное управление на всех уровнях появится вне зависимости от общей антикризисной направленности переходного образовательного процесса. Именно в этот непростой для цивилизации и мирового образования период на первый план выступают в образовании функции адекватного реагирования на современные изменения и даже их кратковременное предвидение, защиты от угроз и опасностей, т.е. обеспечение безопасности в любом ее виде (а не

\footnotetext{
${ }^{11}$ План выполнения решений Всемирной встречи на высшем уровне по устойчивому развитию // Использование и охрана природных ресурсов в России. 2002. № 9-10.
} 


\section{Политика и общество 7 (115) • 2014}

только экологической). Трансляционная функция образования отходит на его периферию, а на приоритетное место выходит созидательно-творческое, развивающее начало, способствующее принятию опережающих решений по выходу из кризисных ситуаций и выживанию. Акцент смещается из области усвоения суммы знаний в область развивающего мышления, сферу творчества - овладения методами принятия решений и опережающего антикризисного моделирования (тренинга).

В упомянутой Национальной доктрине соединены в одно целое элементы прежнего и «желаемого» современниками образования, более адекватного для нашего «переходного» общества. Но поскольку этот переход теперь сопряжен с движением не только по модернизационной стратегии (вписыванием в превалирующую рыночно-демократическую часть мирового сообщества), но и трансформационно-опережающей - переходом к устойчивому обществу, то это ведет и к новому видению образования в формирующейся будущей цивилизации. Образование обретает принципиально новые черты и ориентации, которые представляются приоритетными в образовании для устойчивого развития ${ }^{12}$.

Среди других официальных документов, которые важно использовать для развертывания ОУР в России, - указы Президента РФ по вопросам УР и соответствующие приложения к ним ${ }^{13}$. Особое значение для ОУР приобретают две книги, изданные перед ВСУР, в которых подробно излагаются как научные основы устойчивого развития, так и проблемы перехода к новой цивилизационной стратегии в XXI веке ${ }^{14}$. В России также были проведены парламентские слушания в Государственной Думе РФ на тему: «Об участии Российской Федерации в реализации Стратегии Европейской экономической

\footnotetext{
${ }^{12}$ См.: Урсул А.Д. Российское образование для устойчивого развития: первые шаги в будущее// Alma mater (Вестник высшей школы). 2005. № 8 .

13 Указ Президента РФ «О государственной стратегии по охране окружающей среды и обеспечению устойчивого развития. Основные положения государственной стратегии Российской Федерации по охране окружающей среды и обеспечению устойчивого развития» // Российская газета. 1994. 9 февраля; Концепция перехода Российской Федерации к устойчивому развитию // Российская газета. 1996. 9 апреля.

${ }^{14}$ Научная основа стратегии устойчивого развития Российской Федерации. М., 2002; . Стратегия и проблемы устойчивого развития России в XXI веке. М., 2002.
}

комиссии ООН для образования в интересах устойчивого развития» ещё в мае 2006 г.

\section{Опережсаюций характер ОУР}

К этому необходимо добавить, что идея УР впервые достаточно полно была изложена в книге «Наше общее будущее» (доклад МКОСР или доклад Брундтланд), опубликованного на английском языке еще в 1987 г. ${ }^{15}$. Однако это лишь первые подходы научной аргументации модели УР. В рамках современной науки вряд ли можно будет получить всестороннее доказательство возможности реализации модели УР, для этого необходимо изменить саму модель науки, о чем также шла речь ${ }^{16}$. Именно будущая - ноосферная наука включит в сферу своего познания и реализации модель УР.

К особенностям развития ОУР в Российской Федерации следует отнести ту черту, что здесь впервые было осознано, что наиболее существенной чертой ОУР является не только дальнейшая экологизация образования, но и его футуризация, т.е. смещение акцентов на изучение и моделирование будущего. И понятно почему: модель УР является пока лишь нормативно - прогнозом, который еще предстоит реализовать. Поэтому, наряду с другими характеристиками, ОУР в качестве особенностей, отличающей новую форму (модель) образования от современной (будем называть её еще и традиционной), выделяется опережающий механизм развертывания образовательного процесса. Опережающий механизм, футуризирующий образование, складывается из включения в образование проблемы будущего, а также гораздо более ускоренного (по сравнению с другими видами человеческой материальной деятельности) развития. Именно поэтому ЮНЕСКО полагает, что образование для устойчивого развития представляет собой процесс обучения тому, как принимать решения, нужные для обеспечения долгосрочного будущего экономики, экологии и равенства всех сообществ. Развитие

\footnotetext{
${ }^{15}$ См.: Наше общее будущее. Доклад Международной комиссии по окружающей среде и развитию / Пер. с англ. М., 1989.

16 Урсул А.Д., Урсул Т.А. Наука и образование в глобальноноосферной перспективе // NB: Проблемы общества и политики. 2013. № 02; Ильин И. В., Урсул А. Д. Глобальные исследования и эволюционный подход. М.: Изд-во Московского университета. 2013.
} 
мышления, ориентированного на будущее, - ключевая задача образования в интересах УР 17 .

Ведь в книге «Наше общее будущее», известной как доклад Г.Х. Брундтланд, посвященной обоснованию необходимости перехода к УР, было приведено определение понятия УР: «Устойчивое развитие - это такое развитие, которое удовлетворяет потребности настоящего времени, но не ставит под угрозу способность будущих поколений удовлетворять свои собственные потребности» ${ }^{18}$. Это определение стало наиболее распространенным после его фактического принятия на Конференции ООН по окружающей среде и развитию в 1992 г. в Рио-деЖанейро (ЮНСЕД). Такое определение выражает глубинную сущность новой модели (формы) человеческого развития, которое, по мнению его авторов, не должно прерываться какой-либо глобальной катастрофой антропогенного происхождения.

Между тем опережающий характер экологического и других видов образования, как не раз подчеркивалось, следует из того, что экологические (особенно глобальные) проблемы и их негативнокатастрофические последствия можно только предотвратить, т.е. решение их имеет принципиально упреждающий характер. Ведь ликвидировать последствия глобальной социально-экологической либо иной планетарной катастрофы просто будет некому, единственный способ ее не допустить - это опережающими решениями и действиями ее предотвратить. Если в модели неустойчивого развития самый распространенный способ реагирования на чрезвычайные ситуации, кризисы и катастрофы - это ликвидация их последствий (когда они носят локальный характер), то в новой цивилизационной модели приоритетно-доминирующим способом должно быть их предотвращение (что, кстати, на порядок дешевле в экономическом плане).

Подобная перспектива требует изменения современной модели развития цивилизации с целью постепенной реализации осознанной опережающей потребности в «продолжении гуманизма»

\footnotetext{
${ }^{17}$ См.: Образование для устойчивого развития. Декада ООН по образованию для устойчивого развития (2005 - 2014) [Электронный ресурc]. URL: http:// www.unesco.org (дата обращения: 04.07.2014)

${ }^{18}$ Наше общее будущее. Доклад Международной комиссии по окружающей среде и развитию / Пер. с англ. М., 1989. C. 59.
}

на неопределенные будущие времена. Поскольку эта потребность уже осознана (хотя и не поставлена на приоритетное место), то она представляет собой человеческий интерес, причем долговременного стратегического характера, который все больше должен учитываться по мере перехода к устойчивому будущему.

УР как модели опережающего сбалансированного социоприродного развития должно соответствовать опережающее образование. Идея опережающего образования как «ядра» ОУР заключается в формировании нового сознания человека и человечества в целом, которое не отставало бы от бытия, а его опережало ${ }^{19}$. Ведь с помощью отстающего сознания невозможно предотвратить глобальную антропоэкологическую катастрофу, поскольку в принципе устранение последствий такой катастрофы невозможно (некому будет их устранять). Формирование с помощью опережающего образования эффективных механизмов реализации модели УР должно привести к преодолению инерции модели неустойчивого развития (ведущей к катастрофе) и постепенной эволюции в направлении новой цивилизационной стратегии.

Формирование опережающего сознания, т.е. коллективного сознания, опережающего социальное бытие, а не отстающего от него, произойдет на пути созидания сферы разума. Такое соотношение сознания и человеческого бытия возможно лишь в будущей ноосфере, которая будет формироваться через переход к УР и становление информационного общества. Именно в ноосфере приоритетное место займет не просто разум, а опережающий целостно-коллективный интеллект всего человечества, сформировавшего эту целостность благодаря глобализации через УР. Это станет возможным, если на приоритетное место будут выходить все процес-

\footnotetext{
${ }^{19}$ См.: Урсул А.Д. Модель опережающего образования: ноосферно-экологический ракурс// Модель опережающего образования: ноосферно-экологический ракурс. М., изд-во РАГС, 1996; он же. Модель опережающего образования и переход России к устойчивому развитию // Устойчивое развитие. Вып. 1. М.: ВИНИТИ, 1996; он же: Образование для устойчивого развития: футуризация и инновационно-опережающие процессы // Открытое образование. 2008. № 2; Урсул А.Д. Процесс футуризации и становление опережающего образования // Педагогика и просвещение. 2012. №2; Урсул А.Д., Демидов Ф.Д. Образование для устойчивого развития: научные основы. М., 2004.
} 


\section{Политика и общество 7 (115) • 2014}

сы, связанные с интеллектуально-информационной деятельностью и будет формироваться интегральный ноосферный интеллект цивилизации.

Для образования XXI в. нужна также футуризованная (опережающая) наука, которая не только должна развиваться ускоренными темпами, но и быть ориентированной на нормативный прогноз в форме УР (что не исключает разработку иных поисковых прогнозов, альтернативных сценариев, гипотез и т.д.). Если наука всерьез займется будущим и включит его в сферу своей деятельности столь же полноправно, как это она делает с настоящим и прошлым, то ее ждет «шок будущего», о котором для других областей деятельности писал более сорока лет тому назад Э. Тоффлер в «Футурошоке» (Пер. с англ. М., 2001).

Будущее должно стать в центре внимания ноосферной науки, причем степень футуризации науки будет в существенной степени определять ее ноосферизацию. Наука по мере приближения к своему ноосферному состоянию должна выявить закономерности становления будущего во всех его формах и тем самым реализовать принцип темпоральной целостности и взаимосвязи прошлого, настоящего и будущего. И прежде всего это касается перехода к УР и на этой основе - становления ноосферы.

Свойство опережения в инновационно-образовательном процессе в основном будет касаться целей и содержания образования и в определенной степени организационного статуса, роли всего процесса обучения и воспитания среди других сфер социальной деятельности. Если от нового типа образования зависит переход к устойчивому будущему, то его новый статус и функциональная роль в обществе должна быть узаконена нормативно-правовыми и управленческо-организационными способами и формами.

Включение опережающих механизмов в образовательный процесс и акцент на будущем изменят сам подход к пониманию образования. Если ранее образование сводилось к передаче знаний, умений, навыков, культуры от предыдущих поколений к нынешним, то теперь такая ситуация, как было показано, уже не оказывается адекватной. Вопервых, начиная с последней декады XX века, происходит ежегодное и даже более ускоренное удвоение производимой научной и другой информации. Учитывая этот факт, а также существенное отставание «образовательного» знания от научного знания, можно понять, как мало «эффективной» ин- формации может получить обучаемый. Во-вторых, футуризация образования диктует необходимость получения информации не только о прошлом и настоящем, но и из будущего и о будущем. Причем именно этот вид информации будет играть не менее, а, может быть, и более важную роль, нежели информация о прошлом и настоящем. Мы опятьтаки имеем в виду так называемый «эффект Эдипа», когда решения принимаются с учетом набора поисковых и нормативно-желаемых прогнозов. Вот почему включение «фактора будущего» в образовательный процесс и концентрация усилий на воплощении в действительность модели УР формирует новую, в существенной степени опережающую интерпретацию (модель) образования как ОУР и его роли как в обществе, так и в сфере взаимодействия с природой.

Уместно также сказать несколько слов о соотношении ОУР и опережающего образования. Совершенно очевидно, что это разные типы и формы инновационных процессов в образовании. Опережающее образование включает в себя футуризацию и опережающие механизмы для любых вариантов видения будущего, а не только нормативного УР. И в этом смысле оно может использоваться и вне ОУР, и в любой другой дисциплине, курсе и направлении образования, поскольку это принципиально особый инновационный процесс, акцентирующий внимание на будущем. В этом смысле специального опережающего образования такого же как, например, экологическое и экономическое виды образования быть не может.

Для устойчивой цивилизации необходима новая модель образования, которая могла бы удовлетворять соответствующие (неисчезающие) потребности нынешних и будущих поколений землян и всего человечества в условиях сохранения биосферы. Основные контуры новой модели общественного (цивилизационного) развития и его важнейшей подсистемы - образования должны сформироваться, на наш взгляд, уже в ближайшие десятилетия. В результате ОУР не только «впишется» в эволюцию мирового сообщества по новому пути, но и окажется одним из решающих рычагов грядущего цивилизационного «инновационного перехода». В свою очередь, как одна из важнейших сфер социальной деятельности - образование также перейдет на свой собственный путь УР в соответствии с базовыми принципами УР-трансформаций. 
Первые шиги российского образования в устойчивое будущее

Элементы ОУР в России начали появляться в первые же годы после ЮНСЕД. Впервые в России наиболее широко научные исследования по УР и их использование в педагогическом процессе начались в Ноосферно-экологическом институте Российской академии управления (преобразованного затем в кафедру социальной экологии Российской академии государственной службы при Президенте РФ - РАГС). Здесь на кафедре социальной экологии (затем опять-таки переименованную в дальнейшем в кафедру экологии и управления природопользованием) кроме специальных курсов по указанным выше проблемам, все другие курсы в существенной степени были пронизаны идеей УР. Эти курсы были предназначены как для студентов в области социальной экологии, так и для обучаемых другим специализациям.

Существенное внимание проблемам УР в эти же годы уделялось в Международном независимом эколого-политологическом университете (МНЭПУ), Уже существуют учебные подразделения по устойчивому развитию в Бурятском госуниверситете и в Российском химико-технологическом университете им. Д.И. Менделеева и некоторых других вузах, однако пока их число ограничено (эту же мысль подчеркивает и небольшое количество университетов РФ, подписавших «Обязательства учреждений высшего образования в отношении практики обеспечения устойчивости в связи с Конференцией ООН по устойчивому развитию».

Идет обучение в области устойчивого развития в Дагестанском государственном университете, в Кубанском государственном университете, Владимирском государственном университете, Ивановском государственном университете, СанктПетербургском государственном университете и, конечно, в МГУ им. М.В. Ломоносова, причем не только на географическом факультете (где этому типу образования уделяется наибольшее внимание). МГУ в отношении ОУР занимает особое место среди высших учебных заведений страны. Это единственный вуз, где в Программе развития университета до 2020 года содержится специальный раздел, посвященный проблеме УР, причем подчеркивается, что главной задачей университета на этом этапе станет реализация новой глобальной научно- образовательной политики в интересах российского академического сообщества и страны в целом. В последние годы особое внимание уделяется не только традиционным экологическим, но и другим, в особенности глобальным аспектам перехода к УР в основном на факультете глобальных процессов, что даже привело к формированию нового направления глобалистики - образовательной глобалистики ${ }^{20}$.

Довольно часто, говоря об ОУР, имеют в виду развитие в том или ином вузе экологического образования и, вполне понятно, что вряд ли можно найти сейчас вуз, где бы ни преподавалась экология и природопользование. Однако, далеко не всякое экологическое образование автоматически подпадает под ОУР и даже под ЭОУР как экологическое образование для УР (как, впрочем, и проблемы экологии не совпадают с проблемами УР).

Именно поэтому реально экологическое образование не приобрело такого статуса и его развитие происходит, несмотря на отдельные успехи, по остаточному принципу, оно пока отторгается как всей системой образования, так и самим обществом. И эта ситуация мало будет меняться до тех пор, пока не начнется переход к УР и в других сферах деятельности. Роль экологического образования станет усиливаться в общей системе образования по мере того как эта последняя будет превращаться в систему ОУР. Важно уже сейчас осознать, что экологическое образование в модели НУР (т.е. то, что оно представляет собой в настоящее время) и то, чем

${ }^{20}$ Ильин И.В., Урсул А.Д. Перспективы глобального образования: эволюционный подход // Глобалистика как область научных исследований и сфера преподавания. Вып. 4. М.: МАКС Пресс, 2010; Ильин И.В., Урсул А.Д. Эволюционный подход к глобальным исследованиям и образованию: теоретико-метод. проблемы // Век глобализации. 2010. №1; Урсул А.Д. Глобальное знание и глобальное образование (эволюционный подход). Красноярск: СФУ, 2011; Урсул А.Д. Модель опережающего образования // Глобальный кризис западной цивилизации и Россия. Изд. 3-ое доп. М.: ЛИБРОКОМ, 2012; Урсул А.Д., Лось В.А. Устойчивое развитие как глобальный процесс. Учебнометодическое пособие. М.: МАКСПресс, 2012; Урсул А.Д., Урсул T.A. Наука и образование в глобально-ноосферной перспективе // NB: Проблемы общества и политики. 2013. № 02; Ильин И.В., Урсул А.Д., Урсул Т.А. Глобалистика и глобальные исследования. Глобальная революция в науке. Саарбрюкен (ФРГ): Dictus Publishing.2014; Ильин И.В., Урсул А.Д., Урсул Т.А. На пути к образовательной глобалистике // Вестник Моск. Университета. Серия 27: Глобалистика и геополитика. 2013. № 2. 


\section{Политика и общество 7 (115) • 2014}

должно стать в модели УР - это существенно разные виды образования.

Несмотря на то, что экологическое образование является в определенном смысле инвариантом современного образования и его будущей системы, адекватной УР, в этой последней оно приобретет черты, на которых имеет смысл остановиться далее несколько подробнее.

Во-первых, экологическое образование в модели НУР представляется своего рода инородным образованием, своего рода «имплантантом из будущего». Когда вся современная модель функционирования и развития общества имеет экономоцентрический характер, демонстрируя во всех сферах потребительскую ориентацию, она не приемлет введение экологических императивов, отторгая все, что связано с ограничением получения прибыли и выгоды. Все другие составляющие системы образования модели НУР согласно принципам модели реагируют, начинают «давить» на свою и вместе с тем «чужеродную» составляющую в виде экологического образования. Это противоречие между интересами настоящего и потребностями будущего не может без трудностей и проблем разрешиться в пользу этого последнего (противоречие между современными «экономическими» поколениями и будущими в гипотетическом обществе сУР).

Выход из этой противоречивой ситуации видится в том, чтобы все другие составляющие системы образования - т.е. его экономическая, социально-гуманитарная, технико-технологическая и все остальные также «работали» на переход к устойчивому будущему. Развитие одного экологического образования даже при условии вложения все больших сил и средств, не сможет вывести систему образования на новый уровень, соответствующий целям УР. УР представляет собой систему систему экономических, экологических, социально-культурных и других аспектов человеческой деятельности, ориентированных на цели выживания цивилизации и становление нооосферы, что должно найти адекватное выражение в образовании.

Во-вторых, экологическое образование в модели НУР (как, впрочем, и все остальные виды и формы образования) существенно отстает и от реальной жизни и от переднего края научных исследований. Разумеется, далеко не все экологическое образование может быть охарактеризовано как «от- стающее», в нем есть и «опережающие» черты. Но, находясь в системе «неустойчивого» образования, экологическое образование в должной степени в настоящее время не может стать таким «опережающим образованием», которое адекватно соответствовало бы значимости решения экологических проблем и переходу к УР.

Между тем опережающий характер экологического и других видов образования следует из того, что экологические (особенно глобальные) проблемы можно только предотвратить, т.е. решение их носит принципиально упреждающий характер. Ведь ликвидировать последствия планетарной экокатастрофы просто будет некому, единственный способ ее не допустить - это опережающими решениями и действиями ее предотвратить. Если в модели НУР самый распространенный способ реагирования на чрезвычайные ситуации, кризисы и катастрофы - это ликвидация их последствий (когда они носят локальный характер), то в новой цивилизационной модели приоритетно-доминирующим способом должно быть их предотвращение (что, кстати, на порядок дешевле в экономическом плане).

В-третьих, экологическое образование, как, впрочем, и вся природоохранная деятельность во всем мире, акцентировало свое внимание после Стокгольмской конференции по окружающей среде ООН на локальных проблемах. Улучшение экологической ситуации в отдельно взятой экосистеме, скажем, в конкретном бассейне или городе имеет важное значение для населения этой местности, но подобный подход характерен именно для решения проблем окружающей среды в модели НУР. Увлекшись решением локальных экологических проблем, мировое сообщество спустя два - и тем более три - десятилетия после Стокгольма обнаружило, что глобальная экологическая ситуация не только не улучшилась, но и существенно ухудшилась. Это проявилось в дальнейшем увеличении выбросов парниковых газов, потеплении климата, снижении биоразнообразия, сведении лесов, уменьшении озонового слоя, опустывании, загрязнении атмосферы и акваторий и т.п. И это несмотря на то, что на локальные экологические мероприятия во всем мире были потрачены коллосальные средства, превышающие, возможно, несколько трлн долл. США за три десятилетия. Эта сумма сейчас существенно возросла, а глобальная экологическая перспек- 
тива существенно ухудшилась, акцент на локальной экологической деятельности продолжается, - и все это характерно именно для модели НУР.

И хотя еще Римский клуб в свое время призвал думать глобально, а действовать локально, но этот призыв был понят в основном в смысле проведения локальных мероприятий. Никто и не намеревался, проводя эти мероприятия, чтобы одновременно улучшать и глобальную экологическую ситуацию. Сейчас, имея в виду перспективы устойчивого будущего, необходимо уже и думать и действовать глобально и локально, не разрывая их взаимосвязь на мыслительную и практическую составляющие. Ухудшение экологической ситуации в планетарном масштабе в результате большинства локальных экологических мероприятий произошло потому, что в результате их проведения антропогенное давление на биосферу не уменьшилось, а увеличилось (ведь для их проведения брались ресурсы и ухудшалась среда в других местах планеты). Для очистки, скажем, какого-либо бассейна необходимо затратить энергию и другие ресурсы, взятые в других местах, из других экосистем, что приводит к их нарушению и загрязнению. Все они суммируются на биосферно-глобальном уровне и в результате локальные очистки выглядят как «заметание мусора под кровать», приближая планетарную экокатастрофу.

Вот почему важно при проведении любых экологических мероприятий следить за тем, чтобы глобальная экологическая ситуация не ухудшилась, а еще лучше, если антропогенный пресс на биосферу уменьшался бы за счет всего комплекса природоохранных мероприятий, ориентированных на реализацию целей УР. Переход к УР имеет, как не раз отмечалось, принципиально планетарный характер в силу целостности и сильных экологических взаимосвязей компонентов биосферы. Глобальная безопасность в экологическом и ином смысле приоритетнее, чем безопасность любой части биосферы либо той ее части, которая именуется человечеством. Это следует из системного принципа обеспечения безопасности, согласно которому безопасность более широкой системы приоритетнее безопасности входящих в нее систем и элементов (несмотря на то, что необходимо обеспечивать безопасность всех других объектов безопасности - государства, личности и т.д.).
Решение экологических проблем, в том числе и с помощью экологического образования, - это инновационный прорыв в будущее. Экологический «мост» от модели неустойчивого развития (НУР) к стратегии УР не может сформироваться без экологического образования в его широком понимании. Причем следует согласиться с тем, что даже в модели НУР экологическое образование, согласно мыслям Н.Н. Моисеева, должно иметь приоритетный статус (хотя в действительности дела обстоят по иному), отражая растущую значимость экологической проблемы в выживании цивилизации и сохранении биосферы. И все же, утверждая это, мы вынуждены констатировать явное противоречие модели НУР и проблем экологии, т.е. экофобную сущность этой архаичной цивилизационной модели.

Именно поэтому реально экологическое образование не приобрело такого статуса и его развитие происходит, несмотря на отдельные успехи, по остаточному принципу, оно пока игнорируется и отторгается как всей системой образования, так и самим обществом (по крайней мере, в России, модернизационные реформы которой больше демонстрируют тягу к рыночному фундаментализму вкупе с корупцией и криминалом). И эта ситуация мало будет меняться до тех пор, пока не начнется переход к УР и в других сферах деятельности. Роль экологического образования станет усиливаться в общей системе образования по мере того как эта последняя будет превращаться вначале в экологическое образование для УР (ЭОУР), а затем в более целостную систему ОУР. Важно уже сейчас осознать, что экологическое образование в модели НУР (т.е. то, что оно представляет собой в настоящее время) и то, чем должно стать в модели УР - это существенно разные виды образования.

Модель образования в интересах устойчивого развития, конечно, все больше будет включать в себя проблемы безопасности не только в экологическом ракурсе, о чем уже шла речь ${ }^{21}$. В значительной степени это связано с принятием «Стратегии национальной безопасности Рос-

${ }^{21}$ См.: Урсул А.Д. Модель образования XXI века: безопасность и устойчивое развитие // Безопасность Евразии. 2001.№ 4. 


\section{Политика и общество 7 (115) • 2014}

сийской Федерации до 2020 года» ${ }^{22}$. Эта Стратегия представляет собой не только важнейший официальный документ по проблеме национальной безопасности страны, но и новую - более современную версию российской концепции (а, может быть, и стратегии?) перехода к устойчивому развитию.

В данной Стратегии вводится новое и важное понятие приоритетов устойчивого развития (причем это не только известная и распространенная триада - экономика, экология и социальная сфера), выражающих те основные характеристики, на которых на период до 2020 г. необходимо сосредоточить усилия и ресурсы и которые способствуют достижению необходимого состояния национальной безопасности (статья 24 Стратегии). Среди них:

- повышение качества жизни российских граждан путем гарантирования личной безопасности, а также высоких стандартов жизнеобеспечения;

- экономический рост, который достигается прежде всего путем развития национальной инвестиционной системы и инвестиций в человеческий капитал;

- наука, технологии, образование, здравоохранение и культура, которые развиваются путем укрепления роли государства и совершенствования государственно-частного партнерства;

- стратегическая стабильность и равноправное стратегическое партнерство, которое укрепляется на основе активного участия России в многополярной модели мироустройства.

Это видение этого типа развития с позиции обеспечения основных видов безопасности как России, так и всего мирового сообщества. Принятие Стратегии - важный мировоззренческий и концептуально-методологический поворот в области проблем безопасности и одновременно в сфере проблем устойчивого развития, их объединения в единое научно-поисковое и практическо-деятельностное направления.

Поэтому в принципе осмысление проблем образования для устойчивого развития не обязательно должно идти только через экологию и экологическую безопасность. Можно интерпретировать этот тип развития и образования также через проблемы

22 См.: Стратегия национальной безопасности Российской Федерации до 2020 года // Независимое военное обозрение. 2009. № 16; [Электронный ресурc]. URL: http://www.scrf.gov. $\mathrm{ru} /$ documents/99.html (дата обращения: 04.07.2014) безопасности и через входящие в систему устойчивого развития направления социальной активности (включая обеспечение безопасности), ранее изучавшиеся как относительно автономные формы человеческой деятельности.

В настоящее время завершены проекты Национальной стратегии России в области ОУР и Плана действий в этом направлении ${ }^{23}$, в которых подчеркнуто, что участие РФ в реализации Стратегии соответствует национальным интересам развития страны. Однако для реализации этих документов в стране важно принять нетрадиционные решения на государственном уровне, которые должны будут ориентировать российскую систему образования на новые общемировые цели перехода на магистраль УР. Однако их не удалось принять на федеральном уровне в силу неконструктивной позиции Минобрнауки РФ, которое с тех пор не изменилась.

Ясно, что как и УР, так и ОУР должно иметь системный характер и распространяться на все образовательные дисциплины и курсы, и, в первую очередь, должны развиваться там, где есть больше оснований для включения идей УР в образовательный процесс. Нужно отметить, что конференция «Образование для устойчивого развития», состоявшаяся в декабре 2002 г. в МГУ им. М.В. Ломоносова, рекомендовала разработать государственную стратегию образования в области УР, а также механизмы ее координации с европейской стратегией ОУР. Предполагалось также рассмотреть возможность открытия в системе высшего профессионального образования в группах университетского, инженерно-технического и социально-экономического образования соответствующих специальностей и специализаций для УР.

Еще более пространные и конкретные предложения содержатся в рекомендациях парламентских слушаний на тему «Об участии Российской Федерации в реализации Стратегии Европейской экономической комиссии ООН для образования в интересах устойчивого развития», состоявшихся мае 2006 г. $^{24}$

В свете изложенного выше важно подготовить нормативные документы для внедрения в высшее

\footnotetext{
${ }^{23}$ См.: Касимов Н.С. От экологического образования к образованию для устойчивого развития // Образование для устойчивого развития. Под ред. Н.С. Касимова. М. - Смоленск, 2004.

${ }^{24}$ См.: [Электронный ресурc]. URL: http://www.ustoichivo.ru/ biblio/view/138.html (дата обращения: 04.07.2014)
} 
профессиональное образование специальности в области УР (государственные образовательные стандарты, типовые учебные планы, программы федерального компонента, учебники и учебные пособия и др.).

Уже отмечалось, что важно включить в эту сферу деятельности и законотворческий процесс. В будущий федеральный закон (а лучше кодекс) о переходе России к УР необходимо внести вопросы образования либо, если будет разрабатываться кодекс, то предусмотреть специальный раздел по ОУР. Ясно, что некогда разработанный, но не принятый Советом Федерации закон об экологическом образовании вряд ли будет реанимирован. Ведь важно, чтобы экологическое образование работало не автономно в образовании России, а как составная часть будущего ОУР. Вряд ли уместно специально принимать какие либо «узкоотраслевые» законы (например, в области экологического образования или экологической культуры), когда уже осознана возможность и целесообразность принятия более системных законов об устойчивом развитии.

В настоящее время уже существует ряд учебных программ и курсов по проблемам УР. Насколько нам известно, впервые идеи УР были введены в программы курса «Основы общей и социальной экологии» (М., 1993), в Российской академии управления - РАУ (в дальнейшем это учебное заведение было преобразовано в Российскую академию государственной службы при Президенте РФ - РАГС). Кстати сказать, что и учебное пособие «Введение в социальную экологию» (М., Изд-во «Луч», ч. I 1993, ч II - 1994), написанное под эту программу в Ноосферно-экологическом институте РАУ также впервые связало изложение экологии с устойчивым развитием. Эволюция этой точки зрения привела к тому, что вышедшее в 2005 г. учебное пособие «Общая и социальная экология» (отв. ред. А.Д. Урсул, М., Изд-во РАГС, 2005) излагает экологические проблемы уже не просто в связи с идеей УР, а «через» этот тип развития, что придает определенную методологическую новизну и ноосферную ориентацию взаимосвязи проблем экологии и УР.

В дальнейшем, созданная на базе Ноосферноэкологического института РАУ, кафедра социальной экологии РАГС выпустила программы курса «Основы социальной экологии» (М., 1995), где социально-экологическая проблема тесно увязывалась с переходом мирового сообщества к УР. Кро- ме того, была опубликована программа курса «Проблемы перехода Российского государства на модель устойчивого развития» (М., 1995, авторы - А.Д. Урсул, В.Г. Барский), в которой УР связывалось с развитием феномена государственности. Под эту программу было выпущено в 1995 г. учебное пособие «Перспективы перехода Российского государства на модель устойчивого развития» (автор - А.Д. Урсул, М., РАГС), которое, видимо, было одним из первых, если не первым учебным пособием по УР в России). (Одновременно вышло учебное пособие «Sustainable development. London. Brussels. Paris. 1995. (Ed. B.Nath, L.Hens, D.Devuyst), ставшеe caмым распространенным в Европе). Эта же кафедра издала учебно-методическое пособие по изучению курса «Теория устойчивого развития» (М., 1995, автор - А.Д. Урсул), где был предложен ряд тем, составляющих современную научную концепцию УР.

В дальнейшем в РАГС при Президенте РФ была издана программа по специальности «государственное и муниципальное управление» (специализация «Экология и управление природопользованием» (М., РАГС, 1999. отв. ред. А.Д. Урсул), которая включала темы «Теория устойчивого развития», «Переход Российского государства к устойчивому развитию», «Становление ноосферы: социальноэкологический аспект», где в достаточно развернутом виде излагались проблемы УР.

Упомянутые выше программы курсов предназначались в основном для слушателей (студентов), получающих второе высшее образование в РАГС при Президенте РФ (хотя использовались и для профессиональной переподготовки и повышения квалификации в адаптированном для этих целей формате). Учитывая официальные намерения и перспективы перехода РФ к УР, в РАГС для всех форм обучения велись также занятия по программе курса «Устойчивое экологобезопасное развитие» (М., 1998), под которую в 2001 г. было издано учебное пособие с тем же наименованием. В дальнейшем этот курс был преобразован в курс «Стратегия устойчивого развития» и было издано новое учебное пособие «Устойчивое социоприродное развитие» в 2005 г. (авторы А.Д.Урсул и Ф.Д. Демидов).

В настоящее время в ряде вузов осознана необходимость включения в образовательный процесс курсов по УР. Важным моментом этого процесса является инициатива географического факультета МГУ им. М. Ломоносова по публикации ряда 


\section{Политика и общество 7 (115) • 2014}

программ курсов по устойчивому развитию ${ }^{25}$. Среди них - программа «Устойчивое развитие» (автор - чл. - корр. РАН Н.Ф. Глазовский) для географов МГУ, программа «Основы устойчивого развития» (авторы - Г.Н. Голубев, Ю.Л. Мазуров, Н.С. Мироненко, В.С. Тикунов) для студентов МГУ естественных факультетов, программа «Экономика устойчивого развития» (авторы - С.Н. Бобылев, Э.В. Гирусов, Р.А. Перелет) для студентов в области природопользования и экономики, программа «Устойчивое развитие человечества» (автор - Н.Н. Марфенин) для студентов, изучающих экологию, геоэкологию и природопользование, программа «Устойчивое развитие человечества» (автор - С.А. Литвинская) для студентов естественных факультетов, программа «Основы устойчивого развития» (автор - Т.А. Трифонова) для студентов естественнонаучного профиля, программа «Устойчивое развитие и экологическая политика» (автор Г.М. Воропаева) для студентов-экологов, программа «Проблемы устойчивого развития» (авторы чл. - корр. РАН Н.П. Тарасова, акад. РАО, чл. корр. РАН Г.А. Ягодин, В.А. Петрищев, Н.В. Белотелов, Е.Е. Пуртова) для студентов химико-технологического направления обучения, программа «Основы устойчивого развития» (авторы - Г.М. Абдурахманов, акад. АН Молдавии А.Д. Урсул) для студентов естественного и гуманитарного направлений, программа «Социальная экология и устойчивое развитие» (автор - В.С. Лямин) для студентов естественного и социального направлений.

Мы перечислили эти программы, чтобы иметь общее представление о новом направлении учебно-методической деятельности. Вряд ли можно согласиться с тем, что все эти курсы именуются дисциплинами (до этого еще далеко во всяком случае в научном ракурсе, хотя так почему-то принято их именовать в учебном процессе в России). Чаще всего эти учебные дисциплины ориентированы на студентов естественного профиля и выполнены в основном учеными и педагогами естественнонаучного профиля ${ }^{26}$. Это объясняет-

\footnotetext{
${ }^{25}$ См.: Образование для устойчивого развития. Материалы семинара «Экологическое образование и образование для устойчивого развития». М.-Смоленск: Универсум. Под ред. Н.С. Касимова. 2004.

26 См. например, классический университетский учебник: Марфенин Н.Н. Устойчивое развитие человечества. Учебник. М.: Изд-во Московского университета. 2007.
}

ся тем, что как не раз уже упоминалось, проблемы УР «выросли» из экологии, и только сейчас стал понятен их более широкий характер и устремленность в будущее.

Издания учебных пособий на тему УР, пожалуй, продолжаются более интенсивно лишь с 1997 г., когда появился ряд книг и учебные пособий ${ }^{27}$. Особо следует упомянуть о публикациях издательством «Ступени» серии учебных пособий (большинство с грифом Минобразования РФ под ред. проф. Н.М. Мамедова) ${ }^{28}$.

Можно также ожидать, учитывая специфику российского образования, что пока не появятся государственные образовательные стандарты (ГОС) нового поколения для реализации ОУР, проблема внедрения и развертывания этой формы образования не получит кардинального решения и будет внедряться как и прежде по остаточному принципу. Можно констатировать, что пока в России не существует ГОС'ов, посвященных проблеме УР. Однако уже появились ГОС'ы, где в той или иной

${ }^{27}$ См.: Арский Ю.М., Данилов-Данильян В.И. и др. Экологические проблемы: что происходит, кто виноват, и что делать? М.: МНЭПУ, 1997; Дрейр О.К., Лось В.А. Экология и устойчивое развитие. М., 1997; Дятлов С.А. Основы концепции устойчивого развития. СПб.: Изд-во Санкт-Пт. ун-та экономики финансов, 1998; Абдурахманов Г.М., Урсул А.Д., Мамедов Н.M. Социальная экология. Ч. I и II. Махачкала, 1998; Урсул А.Д. Государство в стратегии устойчивого развития. М.: РАГС, 2000; Лось В.А., Урсул А.Д. Устойчивое развитие М.: Агар, 2000; Устойчивое экологобезопасное развитие / Под ред. А.Д. Урсула. М.: РАГС, 2001; Урсул А.Д., Лось В.А., Демидов Ф.Д. Концептуальные основы устойчивого развития. М.: РАГС, 2003; Общая и социальная экология / Под ред. А.Д. Урсула. М.: РАГС, 2005; Урсул А.Д. Переход цивилизации и России к устойчивому развитию. М.: РАГС. 2005; Миркин Б. М., Наумова Л. Г. Устойчивое развитие: Вводный курс: Учебное пособие М.: Университетская книга, 2006; Акимова Т.А., Мосейкин Ю.Н. Экономика устойчивого развития. М., 2009; Шимова О.С. Устойчивое развитие. Учебное пособие. Минск: Изд-во БГЭУ. 2010; Ягодин Г.А., Пуртова Е.Е. Устойчивое развитие. Человек и биосфера. Учебное пособие. М., 2013 и ряд других.

${ }^{28}$ В серию входят следующие книги: Введение в теорию устойчивого развития. М., 2002; Корниенко В.И. Основы менеджмента устойчивого развития. М., 2002; Мамедов Н.М. Основы социальной экологии. М., 2003; Мунтян М.А., Урсул А.Д. Глобализации и устойчивое развитие. М., 2003; Устойчивое развитие и экологизация школьного образования. М., 2003; Бобылев С.Н., Гирусов Э.В., Перелет Р.А., Креиу Н.С. Экономика и устойчивого развития. М., 2004; Бринчук М.М., Мастушкин М.Ю., Урсул А.Д. Правовые аспекты устойчивого развития. М., 2005. 
степени упоминаются вопросы УР. Так, ГОС высшего профессионального образования по специальности экология (квалификация - эколог), подготовленный Учебно-методическим советом по экологии и устойчивому развитию УМО по классическому университетскому образованию (председатель академик РАН Н.С. Касимов), имеет специальный раздел, посвященный устойчивому развитию. И это вполне оправдано, хотя «географическое» направление в этом стандарте превалирует, что не позволяет его в целостном виде использовать, например, в гуманитарных вузах. Накладываются также неоправданные ограничения на руководство кафедр, включивших ГОС «Экология» в сферу своей образовательной деятельности. Как и к любому ГОС'у к этому стандарту можно предъявить массу претензий, но важно, что УР как проблема нашла свое место (пока еще не достаточно адекватное) в ГОС'ах, пусть и в направлении обучения, ориентированном в основном на естественников (а ведь самые кардинальные УР-трансформации ожидаются именно в социально - гуманитарном знании).

То, что вопросы УР появились в ГОС'е по экологии, вполне объяснимо: ведь стратегия УР выросла из экологических проблем, а не, скажем, экономических, либо социальных, хотя необходимо их рассматривать в комплексе, а еще лучше - в системной целостности. Сейчас важно распространить этот опыт на другие ГОС'ы, касающиеся всех основных отраслей знания и, прежде всего, на естественные, общественные и технические науки.

Уже была сделана попытка создать и внедрить в образовательный процесс ГОС по УР в технических науках Университетом природы, общества и человека в Дубне (в то время ректором и президентом РАЕН проф. О.Л. Кузнецовым). Однако бюрократическая система ведомства, ведающего образованием и наукой, не смогла пока воспринять это нововведение, что подтверждает мысль о том, что ОУР до сих пор выглядит для приверженцев модели НУР как чужеродный интеллектуальный продукт, своего рода «имплантант» из будущего. Однако рано или поздно придется не только создавать инновационные ГОС'ы по вопросам УР, но и формировать их пока по существующему дисциплинарному принципу, принятому в модели НУР в ущерб их междисциплинарному, в принципе - общенаучному характеру.

На наш взгляд, созданию новых поколений ГОС’ов по УР будет предшествовать этап включе- ния проблем УР в ныне существующие стандарты, причем начало этому процессу уже положено как упомянутым стандартом «Экология», так и рекомендациями упомянутых парламентских слушаний и резолюции Всероссийского совещания «Образование для устойчивого развития» (Москва, МГУ, 20 декабря 2002 г.), состоявшемся через несколько месяцев после ВСУР. В упомянутой резолюции, поддержанной Минобразованием РФ, высшим учебным заведениям предлагается продумать внедрение концептуальных основ в области УР в региональные и вузовские дисциплины обучения.

Как видим из изложенного выше, процесс перехода российского образования на магистраль «глобальной устойчивости» уже начался, хотя и не приобрел ещё широкого масштаба. Однако пока федеральная часть дисциплин слабо реагирует на вызов будущего, можно сказать, что идет процесс внедрения идей УР в отдельные ГОС'ы и программы обучения, а не создание специальных ГОС'ов и программ по УР. Как нам представляется, наиболее оптимальный «вход» в ОУР будет связан с внедрением уже разработанных рекомендаций Стратегии ЕЭК ООН при их адаптации к российским условиям и дальнейшим расширением концепции устойчивого развития за пределы преимущественно экологического видения.

\section{Чему обучать: \\ необходимость более целостной концепции устойчивого развития}

Подготовительный комитет Конференции ООН по устойчивому развитию Рио +20 на своей первой сессии, состоявшейся еще в мае 2010 г. распространил доклад Генерального секретаря ООН, в котором отмечалось, что достигнутый на сегодняшний день прогресс в осуществлении решений крупных конференций на высшем уровне по устойчивому развитию оказался под угрозой в результате целого ряда кризисов, которые поразили глобальную экономику в 2008 году. Эта же мысль неоднократно повторялась на самом саммите Рио +20 и даже служила главным аргументом и объяснением весьма скромных результатов, достигнутых в его ходе даже по сравнению с предыдущими аналогичными встречами на высшем уровне под эгидой ООН. Мировой финансово-экономический кризис существенно повлиял на принятие (а также на непринятие) конкрет- 


\section{Политика и общество 7 (115) • 2014}

ных решений по увеличению финансовой помощи на цели УР. Причем становится очевидным, что последствия мировых финансово-экономических кризисов могут стать сопоставимыми по совокупному ущербу с масштабным применением военной силы.

В условиях мирового финансово-экономического кризиса, появились негативные тенденции, которые можно квалифицировать как опасности и угрозы на пути дальнейшего системного продвижения по пути устойчивого развития России, о чем идет речь в принятой в 2009 г. Стратегии национальной безопасности РФ до 2020 года ${ }^{29}$, Эти негативные тенденции проявляются прежде всего в социально-экономической сфере: растет безработица, идет снижение темпов экономического развития, в сложных условиях функционирует банковская система, все больше появляется очагов социальной напряженности, усиливается инфляция, и впервые за многие годы принимался дефицитный бюджет страны. Появляются новые стратегические риски и негативные тенденции в условиях глобальных вызовов и кризисов, нарушающих стабильное поступательное развитие страны, и кроме того, санкции в отношении России со стороны США и ЕС в связи с событиями на Украине.

Тем самым становится очевидным, что достаточно существенное негативное воздействие нынешнего неустойчивого развития на процесс перехода к УР становится серьезным препятствием реализации принципов глобальной устойчивости. Неопределенность и непоследовательность поведения многих стран, в том числе и нашей в отношении перехода к УР, на наш взгляд, имеет еще одну важную причину, о которой практически мало кто говорит. Стоит назвать и рассмотреть эту, возможно, даже главную концептуальную причину (кроме уже упомянутой неготовности большинства населения планеты принимать стратегию УР в ее современном виде).

Эта причина - в весьма слабой разработанности теоретических аспектов стратегии УР и видения глубинной природы глобальной устойчивости. В этом сказался традиционный подход к науке в рыночной стихии, когда идет принижение фундаментальной науки и главенствует сиюминутный прагматический подход, заставляющий развиваться по методу проб и ошибок. На суд общественности вы-

${ }^{29}$ Стратегия национальной безопасности РФ до 2020 года // Российская газета. 2009. 19 мая. носится весьма упрощенная и односторонняя концепция УР, которая не является достаточно адекватной, поскольку выделяет в основном экологический аспект и его связь с экономикой и социальной сферой. Несмотря на то, что переход к УР может потребовать принятия различных мер в каждом из государств, сейчас усилия по формированию устойчивого будущего предполагают комплексный подход к деятельности в основном в трех ключевых областях - экономике, социальной сфере и экологии. С этой «триединой» точки зрения формирование новой стратегии развития означает постепенное соединение в единую самоорганизующую систему экономической, экологической и социальной сфер деятельности. В этом смысле устойчивое развитие должно характеризоваться (как минимум) экономической эффективностью, биосферосовместимостью и социальной справедливостью при общем снижении антропогенного пресса на биосферу.

Безусловно, это делать необходимо, но этого недостаточно, ведь никто нам не гарантирует, что переход от экономоцентризма модели НУР к триединству модели УР не вызовет те же проблемы, с которыми глобальный мир сталкивается при реализации нынешней концепции УР. Поэтому важно расширить предметное поле исследования проблемы глобальной устойчивости, сделать концепцию УР более системно-целостной и тем самым более адекватной. А это также означает, что итоги Рио+20, наверное, будут серьёзным основанием для модификации взглядов и более целостного представления этой проблемы в контексте совокупности (уже принятых) решений, о чём уже заявил советник Президента РФ А.И.Бедрицкий ${ }^{30}$.

За последние 20 лет концепция устойчивого развития в России и мире рассматривалась в основном в природоохранной плоскости. Между тем, окружающая среда и развитие являются не двумя отдельными областями, а двумя аспектами одной и той же повестки дня. Требуется существенно более комплексный и целостный подход к формированию стратегий устойчивого развития, обеспечивающий учет не только экологических и социальных издержек экономического роста, на чем сейчас акцентируют внимание.

\footnotetext{
${ }^{30}$ См.: Бедрицкий А.И. Об итогах Конференции ООН по устойчивому развитию «РИО+20» // Природно-ресурсные ведомости. №6 (381), июнь 2012 г.
} 
Разумеется, необходима новая экономика развития, способная обеспечить рост благосостояния общества без дополнительной нагрузки на природную систему - называемой экспертами «экологономикой» или сейчас чаще - зеленой экономикой. Однако устойчивое развитие как новая форма эволюции цивилизации в принципе должно быть направлено против всех кризисных явлений и катастроф (а не только экологического, экономического и социального характера), в том числе и кризисов и даже антропогенных циклов глобального развития, имеющих негативные составляющие и последствия. Появление же кризисных явлений такого рода как глобальный экономический кризис, оказавших негативное влияние не только на экономику и многие другие сферы, но и на переход к УР, свидетельствует о том, что принятая концепция и стратегия УР оказалась пока недостаточно системно-целостной и, тем самым, недостаточно адекватной. В перспективе концепция УР должна быть распространена не только на упомянутую триаду, а на все основные сферы человеческой деятельности, с тем, чтобы сформировать сбалансированное глобальное развитие.

Экологический акцент в этой концепции явился правильным, но лишь первым шагом, ориентированным на длительную, стратегическую перспективу. Устойчивое развитие в этом понимании предполагает выживание цивилизации и даже повышение качества жизни всего населения планеты без роста масштабов использования природных ресурсов и без деградации окружающей среды до таких пределов, что это не привело бы к превышению несущей емкости Земли как целостной социоэкосистемы.

Но теперь ясно, что этого недостаточно и устойчивой глобальной перспективы можно и не достигнуть, если не учитывать различного рода вызовы и угрозы УР со стороны современной рыночной экономики. И не только экономики, экологии и социальной сферы, но и политики, да и ряда других существенных сторон реальной жизнедеятельности человечества. В этом сказалось противоречие между провозглашенной новой формой развития цивилизации и нынешней формой неустойчивого развития. Новая модель развития цивилизации оказалась, с одной стороны, более перспективной, поскольку именно с ее помощью цивилизация сможет выжить. Но, с другой стороны, созданная пока на теоретическом уровне, эта модель оказывается менее системной и не учитывает еще многие составляющие в плане развития и безопасности, которые характеризуют современную модель развития, часто именуемую моделью неустойчивого развития (НУР). Именно эти составляющие «тянут назад» движение в правильном, но недостаточно системном, весьма урезанном направлении. Устойчивому будущему противостоят угрозы со стороны пока не включенных областей деятельности (они-то продолжают развиваться в рамках модели НУР) и они существенно тормозят прогресс на пути к УР экологической ориентации.

Нужно также иметь в виду, «экологическое измерение» движения по пути УР оказывается лишь началом осознания смысла нового пути в глобальное устойчивое будущее. Экологическая проблема в ее глобальном видении оказывается лишь частью того общего процесса, который требует решения всех глобальных проблем, на что уже было обращено внимание, как только была принята эта концепция и стратегия ${ }^{31}$. Не следует представлять (и тем самым зауживать), что главное в переходе к УР это решение экологических проблем, ставших теперь уже глобальными. Речь должна идти о всех глобальных проблемах и негативных общепланетарных процессах, которые должны решаться на пути перехода к УР.

Глобальные проблемы, другие глобальные феномены, тесно связанные с космическими процессами, возникли именно благодаря пространственной шарообразности и тем самым замкнутости нашей планеты как небесного тела, глобальной ограниченности земного шара и его биосферы, в которой развертывается антропогенная деятельность. Глобализация и ряд других социоприродных глобальных процессов уже были «запрограммированны» природными особенностями земного шара, на что выше уже обращено внимание. Глобализация оказалось обусловленной природными характеристиками и особенностями биосферы и даже космическими свойствами планеты как небесного тела. В этом пространственно-природная специфика всех глобальных процессов, включая глобализацию и глобальные проблемы.

Эта особенность глобализма как особого системного миропонимания не всегда осознается и очень

\footnotetext{
${ }^{31}$ См.: Урсул А.Д. Путь в ноосферу. Концепция выживания и устойчивого развития цивилизации. М., 1993.
} 


\section{Политика и общество 7 (115) • 2014}

часто внимание акцентируется лишь на расширительных и связующих фрагменты социума тенденциях, хотя появляющиеся при этом ограничения и пределы оказываются имманентно связанными с этим пространственно-темпоральным расширением. Пространственный аспект глобализма начал осознаваться в первую очередь.

Однако кроме пространственного, весьма важен и темпоральный аспект глобального мышления. Вряд ли в понятии глобализма можно ограничиться только пространственным аспектом, что фактически и имело место по «умолчанию». Такое «пространственное» миропонимание глобализма разрывает реальную взаимосвязь пространства и времени (против чего всегда выступал В.И. Вернадский) в мышлении и деятельности. Важно выявить особенности глобального мировоззрения и в темпоральном ракурсе, причем его можно видеть в том, что будет существенно расширяться временной диапазон, горизонт видения глобальных процессов (как в прошлое, так и в будущее), а также учитываться нелинейное течение и системная взаимосвязь периодов (модусов) времени. Расширение горизонта видения касается как прошлого, так и будущего, не говоря уже о настоящем, но вместе с тем особо стоит сделать акцент на процессе футуризации, который генерирует появление опережающих механизмов во всех сферах деятельности.

Глобализация (и футуризация) времени проявляется не столь очевидно как в пространственных измерениях, но, следуя за ними, в силу сущностной взаимосвязи пространства и времени, это последнее наполняется новыми характеристиками, которые не столь существенны для «доглобального» миропонимания. Глобальный подход позволяет видеть будущее человечества вовсе не как простое и все продолжающееся расширение Ойкумены, а вносит принципиально новые нелинейные коррективы в перспективы эволюционных процессов с участием человека.

В предметную область создаваемой теории УР должна будет войти вся антикризисная и «циклическая» проблематика. Ведь глобализация человеческой деятельности сопряжена в силу сказанного с усилением кризисно-циклических явлений во всех сферах активности людей из-за появления ограничений и пределов. Если взять циклические явления, которые стали изучаться в экономике, то, вопрос серьезно не ставился о возможности и необходимости их устранения или снижения (по крайней мере, понижательных фаз). Речь шла в основном о признании их объективности и понимания того, как они развиваются. Между тем, в условиях усиления действия глобальных ограничений будут расти и отрицательные последствия кризисно-циклических феноменов во всех сферах деятельности человека. Поэтому важно изучение этих процессов связать с проблемой перехода к УР.

Ведь если этого не произойдет, то переход к УР не будет реализовываться и опять придется констатировать, что надежды не только экологов, но и других сторонников такого перехода опять окажутся не реализованными. Поэтому становится понятным, что будущая теория УР должна оказаться гораздо шире, чем это представляет большинство ученых, которые занимаются «устойчивой» проблематикой. И это важно учитывать в становлении ОУР, который в силу указанных обстоятельств должен будет расширять свою сферу в научно образовательном пространстве.

\section{Библиография:}

1. Ващекин Н.П. Делокаров К.Х., Урсул А.Д. Образование и устойчивое развитие. Концептуальные проблемы. М., 2001.

2. Всемирная декларация о высшем образовании для XXI века: подходы и практические меры. [Электронный ресурс]. URL: http://www. conventions.ru/view_base.php?id=1496 (дата обращения: 04.07.2014)

3. Заявление об образовании в интересах устойчивого развития // Конференция министров «Окружающая среда для Европы». Киев. 2003.

4. Ильин И. В., Урсул А. Д. Глобальные исследования и эволюционный подход. М.: Изд-во Московского университета. 2013.

5. Ильин И.В., Урсул А.Д., Урсул Т.А. Глобалистика и глобальные исследования. Глобальная революция в науке. Саарбрюкен (ФРГ): Dictus Publishing. 2014.

6. Ильин И.В., Урсул А.Д., Урсул Т.А. На пути к образовательной глобалистике // Вестник Моск. Университета. Серия 27: Глобалистика и геополитика. 2013. № 2.

7. Итоговый документ Конференции ООН по устойчивому развитию «Будущее, которого 
мы хотим» [Электронный ресурс]. URL: http:// www.un.org/ru/sustainablefuture (дата обращения: 04.07.2014)

8. Наше будущее. Доклад Международной комиссии по окружающей среде и развитию / Пер. с англ. М., 1989.

9. Образование для устойчивого развития. Материалы семинара «Экологическое образование и образование для устойчивого развития». М.Смоленск: Универсум. Под ред. Н.С. Касимова. 2004.

10. Основные положения проекта плана осуществления «Десятилетия образования в целях устойчивого развития». ЮНЕСКО. 2003

11. Проект Международного плана мероприятий в рамках Десятилетия образования в интереcax устойчивого развития Организации Объединенных Наций [Электронный ресурс]. URL: http unesdoc unesco org images 0013001390 139023r pdf (дата обращения: 04.07.2014)

12. Стратегия ЕЭК ООН для образования в интересах устойчивого развития. [Электронный pecypc]. URL: http://www.ustoichivo.ru/biblio/ view/145.html (дата обращения: 04.07.2014)

13. Урсул А.Д. Модель опережающего образования и переход России к устойчивому развитию // Устойчивое развитие. Вып. 1. М.: ВИНИТИ, 1996.

14. Урсул А.Д Глобальное знание и глобальное образование (эволюционный подход). Красноярск: СФУ, 2011.

15. Урсул А.Д. Модель опережающего образования // Глобальный кризис западной цивилизации и Россия. Изд. 3-ое доп. М.: ЛИБРОКОМ, 2012.

16. Урсул А.Д. Модель образования XXI века: безопасность и устойчивое развитие // Безопасность Евразии. 2001. .№ 4.

17. Урсул А.Д. Российское образование для устойчивого развития: первые шаги в будущее // Alma mater (Вестник высшей школы). 2005. № 8.

18. Урсул А.Д., Демидов Ф.Д. Образование для устойчивого развития: научные основы. М.: РАГС, 2004

19. Экологическое образование и устойчивое развитие / Под ред. А.Д. Урсула. М.: РАГС, 1996.

20. Элиас В.В. Обзор важнейших международных соглашений в области образования для устойчивого развития // Образование для устойчи- вого развития: Материалы Всероссийского совещания «Образование для устойчивого развития»/ Под ред. Н.С.Касимова, В.С.Тикунова. Смоленск. 2003.

21. Е. Б. Ганюшкина Формирование международного экономического порядка // Международное право и международные организации / International Law and International Organizations. - 2012. - 1. - C. 10-33.

22. Бояркина О.А. Межгосударственные противоречия по использованию трансграничных водных ресурсов в центральноазиатском регионе и роль России. // Политика и Общество. -2013. - 12. - С. 1518-1527. DOI: 10.7256/18128696.2013.12.10578.

23. Бабин Б.В. Право на развитие как глобальное право: международное и национальные измерения // NB: Международное право. - 2013. - № 2. - C.67-84. DOI: 10.7256/2306-9899.2013.2.5108. URL: http://e-notabene.ru/wl/article_5108.html

24. Лось В.А. Экологические итоги развития цивилизации на рубеже XX-XX1вв. (предварительный анализ) // NB: Философские исследования. - 2013. - № 10. - C.121-141. DOI: 10.7256/23060174.2013.10.8931. URL: http://e-notabene.ru/fr/ article_8931.htm

25. В.Ю Яныгин. Вопросы устойчивого развития и будущего экономики России в XXI веке. // Тренды и управление. - 2013. - № 2. - С. 218226. DOI: $10.7256 / 2307-9118.2013 .2 .8015$

26. О.Е. Баксанский. Коэволюционное мышление в контексте конвергентных технологий: от биологии к культуре. // Философия и культура. 2013. - № 9. - С. 1307-1313. DOI: 10.7256/19992793.2013.9.7208

27. Ю.П. Кравченко. Экологические проблемы как отдаленные следствия становления науки Нового времени. // Философия и культура. - 2013. - № 3. - С. 279-288. DOI: 10.7256/19992793.2013.03.2

28. Н. Д. Вершило. Модернизация и охрана окружающей среды: проблемы и перспективы. // Право и политика. - 2012. - № 5. - С. 949-852.

29. Г.Я. Адуховский. Экологический лоббизм, как инструмент защиты природных ресурсов. // Политика и Общество. - 2011. - № 10. - С. 27-31.

30. М. Т. Гогаева. Правовое понятие «экологически значимые решения». // Право и политика. -2011 . - № 3 . 


\section{Политика и общество 7 (115) • 2014}

31. М.В. Шугуров. Международно-правовое регулирование трансфера технологий в целях сохранения и устойчивого использования биоразнообразия: проблемы и решения. // Право и политика. - 2010. - № 8.

32. О.Л. Дубовик. Тенденции правового регулирования энергосберегающих технологий в европейском праве. // Международное право и международные организации / International Law and International Organizations. - 2010. - № 2.

\section{References (transliteration):}

1. Vashchekin N.P. Delokarov K.Kh., Ursul A.D. Obrazovanie i ustoichivoe razvitie. Kontseptual'nye problemy. M., 2001.

2. Il'in I. V., Ursul A. D. Global'nye issledovaniya i evolyutsionnyi podkhod. M.: Izd-vo Moskovskogo universiteta. 2013.

3. Il'in I.V., Ursul A.D., Ursul T.A. Globalistika i global'nye issledovaniya. Global'naya revolyutsiya v nauke. Saarbryuken (FRG): Dictus Publishing. 2014.

4. Il'in I.V., Ursul A.D., Ursul T.A. Na puti k obrazovatel'noi globalistike // Vestnik Mosk. Universiteta. Seriya 27: Globalistika i geopolitika. 2013. № 2 .

5. Ursul A.D. Model' operezhayushchego obrazovaniya i perekhod Rossii k ustoichivomu razvitiyu // Ustoichivoe razvitie. Vyp. 1. M.: VINITI, 1996.

6. Ursul A.D Global'noe znanie i global'noe obrazovanie (evolyutsionnyi podkhod). Krasnoyarsk: SFU, 2011.

7. Ursul A.D. Model' operezhayushchego obrazovaniya // Global'nyi krizis zapadnoi tsivilizatsii i Rossiya. Izd. 3-oe dop. M.: LIBROKOM, 2012.

8. Ursul A.D. Model' obrazovaniya XXI veka: bezopasnost' i ustoichivoe razvitie // Bezopasnost' Evrazii. 2001. .№ 4.

9. Ursul A.D. Rossiiskoe obrazovanie dlya ustoichivogo razvitiya: pervye shagi v budushchee // Alma mater (Vestnik vysshei shkoly). 2005. № 8.

10. Ursul A.D., Demidov F.D. Obrazovanie dlya ustoichivogo razvitiya: nauchnye osnovy. M.: RAGS, 2004

11. Elias V.V. Obzor vazhneishikh mezhdunarodnykh soglashenii v oblasti obrazovaniya dlya ustoichi- vogo razvitiya // Obrazovanie dlya ustoichivogo razvitiya: Materialy Vserossiiskogo soveshchaniya "Obrazovanie dlya ustoichivogo razvitiya"/ Pod red. N.S.Kasimova, V.S.Tikunova. Smolensk. 2003.

12. E. B. Ganyushkina Formirovanie mezhdunarodnogo ekonomicheskogo poryadka // Mezhdunarodnoe pravo i mezhdunarodnye organizatsii / International Law and International Organizations. - 2012. - 1. - C. 10-33.

13. Boyarkina O.A. Mezhgosudarstvennye protivorechiya po ispol'zovaniyu transgranichnykh vodnykh resursov $v$ tsentral'noaziatskom regione i rol' Rossii. // Politika i Obshchestvo. 2013. - 12. - C. 1518-1527. DOI: 10.7256/18128696.2013.12.10578.

14. Babin B.V. Pravo na razvitie kak global'noe pravo: mezhdunarodnoe i natsional'nye izmereniya // NB: Mezhdunarodnoe pravo. - 2013. - № 2. - S.6784. DOI: $10.7256 / 2306-9899.2013 .2 .5108$. URL: http://e-notabene.ru/wl/article_5108.html

15. Los' V.A. Ekologicheskie itogi razvitiya tsivilizatsii na rubezhe KhKh-KhKh1vv. (predvaritel'nyi analiz) // NB: Filosofskie issledovaniya. - 2013. - № 10. - S.121-141. DOI: 10.7256/23060174.2013.10.8931. URL: http://e-notabene.ru/fr/ article_8931.htm

16. V.Yu Yanygin. Voprosy ustoichivogo razvitiya i budushchego ekonomiki Rossii v XXI veke. // Trendy i upravlenie. - 2013. - № 2. - C. 218-226. DOI: 10.7256/2307-9118.2013.2.8015

17. O.E. Baksanskii. Koevolyutsionnoe myshlenie v kontekste konvergentnykh tekhnologii: ot biologii k kul'ture. // Filosofiya i kul'tura. - 2013. - № 9. - C. 1307-1313. DOI: 10.7256/19992793.2013.9.7208

18. Yu.P. Kravchenko. Ekologicheskie problemy kak otdalennye sledstviya stanovleniya nauki Novogo vremeni. // Filosofiya i kul’tura. - 2013. - № 3. -C. 279-288. DOI: 10.7256/1999-2793.2013.03.2

19. N. D. Vershilo. Modernizatsiya i okhrana okruzhayushchei sredy: problemy i perspektivy. // Pravo i politika. - 2012. - № 5. - C. 949-852.

20. G.Ya. Adukhovskii. Ekologicheskii lobbizm, kak instrument zashchity prirodnykh resursov. // Politika i Obshchestvo. - 2011. - № 10. - C. 27-31.

21. M. T. Gogaeva. Pravovoe ponyatie «ekologicheski znachimye resheniya». // Pravo i politika. - 2011. - № 3 . 
22. M.V. Shugurov. Mezhdunarodno-pravovoe regulirovanie transfera tekhnologii $\mathrm{v}$ tselyakh sokhraneniya i ustoichivogo ispol'zovaniya bioraznoobraziya: problemy i resheniya. // Pravo i politika. -2010 . - № 8 .
23. O.L. Dubovik. Tendentsii pravovogo regulirovaniya energosberegayushchikh tekhnologii $\mathrm{v}$ evropeiskom prave. // Mezhdunarodnoe pravo i mezhdunarodnye organizatsii / International Law and International Organizations. - 2010. - № 2. 